\title{
Leksyka dotycząca „najstarszego zawodu świata" w polskim socjolekcie przestępczym z XIX i początku XX wieku
}

\section{Tytułem wstępu}

Przystępując do rozpatrzenia prostytucji w epoce dzisiejszej, gdzie dotykalność faktów, związek ich z innemi życiowemi objawami, a nadewszystko żywotność wymagalników społecznych, prawnych i policyjnych, jasnych wymagają określeń, przedewszystkiem zadamy sobie pytanie: kogo właściwie za prostytutkę uważać należy? Opinja publiczna, jeślibyśmy ją tu za normę przyjąc chcieli, nie daje nam ścisłych i stałych definicji. Każden rozszerza lub ścieśnia pojęcie nierządu w miarę ogólnych swych poglądów lub chwilowego widzi mi się. [...] Podług definicji Ulpjana, nie tylko ta kobieta jest nierządnicą, która oddaje się w domu publicznym, ale i każda któraby w innem miejscu wstydu swego niezachowywała i oddawała się bez wyboru choćby nie biorąc pieniędzy, ta zaś któraby się nawet za pieniądze oddawała nie będzie nierządnicą, gdy w tem utrzymania swego nie szuka.

[...] Cywilizacja wraz ze wszystkiemi swemi cennemi darami przyniosła i poronione płody. [...] Powstają całe klassy nie mogących lub niechcących się żenić i proporcjonalnie do tego objawu wzrasta żądanie na nieprawe związki. Zaofiarowanie $[. .$.$] zjawia się natychmiast, thumy nierządnic roją się po$ ulicach każdego większego miasta, gnieżdżą się po wszystkich jego zaułkach i świadczą do jakich rozmiarów dochodzi zło, którego korzenie tkwią głęboko we wszystkich wadach społecznego ustroju (Kamiński 1875:102-103, 107-108; zachowano pisownię oryginału). 
Fragmenty opracowania Jana Maurycego Kamińskiego z 1875 roku, nawet jeśli mogą się wydawać za długie dla opracowania językoznawczego, przytoczono na początku artykułu nie bez powodu. To dlatego, że - jak dowodzą - zagadnieniem prostytucji i w ogóle życia seksualnego człowieka żywo zajmowano się od dawna, podejmując je z różnych perspektyw: społecznych, prawnych czy medycznych, a mimo to liczba opracowań językoznawczych podejmujących temat erotyki (seksualności człowieka) wciąż nie jest pokaźna - także w Polsce, a jeśli już problematyka ta staje się obiektem obserwacji, to przeważnie analizy dotyczą językowego lub tekstowego obrazu kobiety i mężczyzny. Jeszcze mniej uwagi poświęca się badaniom socjolektalnej leksyki erotycznej, zwłaszcza tej należącej do języka środowisk kryminalnych i widzianej w perspektywie diachronicznej (zob. między innymi: Pacuła 2009, 2017, Krótki 2014, Skowronek 2012, Rejter 2014, 2016). Tymczasem to właśnie język, szczególnie jego system słownikowy, najlepiej odzwierciedla i dokumentuje zjawiska społeczne i kulturowe, stosunek do nich, reakcje na nie. To szczególnie ważne, jeśli uwzględni się, że ,język może się urzeczywistniać tylko w społeczeństwie, i ponieważ w ogóle rozwój psychiczny człowieka jest możliwy tylko w obcowaniu z innymi ludźmi, wiec mamy prawo powiedzieć, że językoznawstwo jest nauką psychologiczno-socjologiczną" (Baudouin de Courtenay 1891:92-115). Niniejszy tekst $w$ drobnej części uzupełnia wspomnianą lukę i dołącza do dwóch istotnych opracowań, które tematycznie się z nim łączą, choć ujmują kwestię przede wszystkim w aspekcie synchronii i opierają się na materiale należącym do potocznej odmiany polszczyzny: po pierwsze, do artykułu Stanisława Kani „Kobieta lekkich obyczajów w języku polskim”, w którym badacz poddał analizie określenia lubieżnych kobiet, ale z uwagi na ogrom materiału (językoznawca doliczył się około czterystu nazw) ogólnikowych, czasem bez pogłębionej refleksji na temat ich pochodzenia (Kania 1976); po drugie, do artykułu Renaty Przybylskiej „Współczesne polskie słownictwo erotyczne”, w którym nazwy „nieżądnych kobiet" są niewielkim wyimkiem analizowanego materiału (sytuują się obok określeń stosunku seksualnego i masturbacji, nazewnictwa męskich i żeńskich narządów płciowych oraz określeń środków antykoncepcyjnych) (Przybylska 1987).

W niniejszym artykule przedmiotem obserwacji uczyniono słownictwo funkcjonujące w polskim socjolekcie przestępczym z XIX wieku i dwóch pierwszych dekad następnego stulecia, a należące do pola tematycznego „prostytucja”. Tekstami objętymi ekscerpcją są (w kolejności chronologicznej): „Język złoczyńców” z 1859 roku, „Gwara złoczyńców” z 1867 roku, „Żargon złodziejski we Lwowie” z 1892 roku, „Słownik mowy złodziejskiej” z 1899 roku, „Kumać po lembersku. Przyczynek do słownika...” z 1901 roku, „Szwargot więzienny” z 1903 roku oraz wydany w 1922 roku „Żargon mowy przestępców”. Pozyskane dane

\footnotetext{
${ }^{1} \mathrm{~W}$ dalszych partiach tekstu posługuję się skrótami odnoszącymi się do wspomnianych opracowań; wykaz tych skrótów i ich rozwinięcia - podobnie jak innych skrótów zastosowanych w tekście - znajduje się na końcu artykułu.
} 
językowe skonfrontowano z notacjami obecnymi w opracowaniach poświęconych językowi przestępczemu po drugiej wojnie światowej, a ponadto - z uwagi na to, że słownictwo socjolektalne często przenika do języka potocznego - zweryfikowano jego obecność w historycznych i współczesnych słownikach ogólnych, słownikach polszczyzny ogólnej i opracowaniach dotyczących leksyki wulgarnej, przekleństw, sfery seksualnej. Ponadto, ustalając etymologię poszczególnych określeń, sięgnięto także do rosyjskich i niemieckich historycznych opracowań poświęconych mowie przestępców. Materiał leksykalny poddany obserwacji liczy trzydzieści osiem jednostek, z czego trzy to nazwy domu publicznego (bajzel, jatka, majdan), dwadzieścia dziewięć jest określeniami kobiet źle prowadzących się (binia, meliniarka, nafke, marucha, lupa, kotka / kotycha / kocicha / kucicha, chonte, prawiczka, babustyna, larwa, pikielowa, prostodziura, ćma, szantrapa, ścierka, rachla, szubraczka, gonia, szlaja / szlajka, poduszka, skówa [zapis oryginalny], rogówka, wytyczka / wytyżka, strychówka), pozostałe, w liczbie sześciu, są mianami „opiekunów” prostytutek (przydupnik, maciornik, luj, kot, brat polski, alfons $)^{2}$. Uwzględnienie poza nazwami miejsc uprawiania nierządu także dwóch wspomnianych subkategorii słownictwa określającego osoby jest istotne, wszak - zwracają uwagę znawcy tematu, pisząc o dziewiętnastowiecznej prostytucji ,[k]lient i prostytutka to - jak wiadomo - nie jedyni aktorzy prostytucyjnej sceny. Role wcale nie epizodyczne grali organizatorzy prostytucji i różnego rodzaju opiekunowie prostytutek - stręczyciele (rufianie, fryerzy), faktorzy, »przedsiębiorcy « prowadzący nielegalne domy publiczne, sutenerzy-alfonsi, najemcy lokali” (Sikorska-Kulesza 2004:142).

Analizowany krąg leksyki łączy się z kwestią tabu, wszak dotyczy ona sfery erotyki, a mówienie o tym - w przypadku języka środowisk dewiacyjnych - wiąże się przede wszystkim ze wstydem wewnątrzgrupowym, związanym raczej z chęcią zachowania własnej intymności niż poruszaniem kwestii seksualnych w ogóle (Widłak 1963, por. Dąbrowska 2002, 2009, 1994:250-254). Zasygnalizowana selektywność tabu wynika z sytuacji, w jakiej analizowane słowa funkcjonowały, specyficznego środowiska używającego tych określeń stąd w zgromadzonym materiale obecność eufemizmów (łagodzących mówienie o nierządzie) i jednocześnie kakofemizmów (dysfemizmów), słów dosadnych, wulgarnych (ujawniających emocje mówiących względem zjawiska prostytucji,

${ }^{2}$ Część materiału odnotowuje SsP Lewinsona, przy czym autor słownika nie zawsze podaje poprawne informacje o pochodzeniu jakiegoś określenia, nie eksponuje też socjolektalnego charakteru niektórych jednostek. Jeśli chodzi o leksykę należącą do kategorii tematycznej omawianej w niniejszym tekście, to $\mathrm{w}$ opracowaniu Lewinsona sprawa przedstawia się następująco: w polszczyźnie od XV do XX występują w sumie 43 określenia domu publicznego, aż 1531 określeń odnosi się do kobiety lekkich obyczajów, z kolei nazwy sutenerów występują w liczbie 125, obok 35 określeń osób prowadzących domy publiczne (Lewinson 1999:348). 
łamiących tabu językowe) ${ }^{3}$. Nieodłączna od tego jest jednak ekspresywność badanej leksyki - każdorazowo bowiem jej użycie uzewnętrznia stosunek mówiących do omawianej sfery rzeczywistości, wyraża sądy i wartościuje (Grabias 1988:37, Puzynina 1986:120-121, Allan/Burridge 2006:29-31). Szczególnie widoczne jest to w przypadku zgromadzonych nazw osób - tak samych prostytutek/kochanek, jak i współorganizatorów „niecnego” procederu 4 .

\subsection{Analiza - określenia domu publicznego}

W XIX stuleciu „[o]pinię miejsc, gdzie oferowano nielegalne usługi seksualne, miały, jak już była o tym mowa, wszelkiego rodzaju lokale gastronomiczne, [przy czym - J.P.] tajne quasi-domy publiczne odkrywano niekiedy w magazynach mód, biurach pośrednictwa pracy, ale najwięcej wypadków dotyczy prywatnych mieszkań" (Sikorska-Kulesza 2004:143-144). W źródłach objętych ekscerpcją natrafiono na trzy określenia domu publicznego. Zasadniczo są to słowa znane polszczyźnie ogólnej, pochodzące z okresu wcześniejszego niż XIX wiek, które w mowie przestępczej przyjęly dodatkowe sensy. Trzeba przy tym zaznaczyć, że te nowe znaczenia raczej nie zrodziły się na gruncie rodzimego socjolektu, zostały zaadaptowane z socjolektów kryminalnych należących do innych języków narodowych. Do omawianych leksemów zaliczają się:

- bajzel 'dom nierządu' (ŻMPLUDWA) - słowo jest dziś znane polszczyźnie także w innych znaczeniach ('bałagan; zamieszanie'), z reguły wywodzi się je wprost z języka niemieckiego (Beisel / Beißl 'knajpa'), jednak nie można wykluczyć, że w polszczyźnie pojawiło się ono jako bezpośrednia pożyczka z jidysz (לתיב[י] 'dojek', por. hebr. bajit [תיבב] 'dom'), wszak oddziaływanie jidysz na język polskich złoczyńców w XIX wieku było bardzo silne ${ }^{5}$ (za tą tezą przemawia zresztą fakt, że w języku wschodnioniemieckim słowo w znaczeniu 'tawerna, knajpa' również pojawiło się jako dziewiętnastowieczna pożyczka z Rotwelsch, w którym z kolei od XV wieku Bajis [Buß] to 'dom', a od dziewiętnastego stulecia Baitz / Beitzle / Baisel to 'zajazd, karczma' [Pfeifer red. 1989:93, Kluge red. 2001:106, Klepsch 2004:303-304]); bajzel jako wyraz socjolektalny o znaczeniu 'dom publiczny', funkcjonujący w środowisku przestępczym w drugiej połowie

3 Oczywiście, nie można pominąć faktu, że cechą eufemizmu jest jego relatywność: „Dana jednostka staje się eufemizmem $\mathrm{w}$ zestawieniu $\mathrm{z}$ inną, która $\mathrm{z}$ punktu widzenia przyjętej $\mathrm{w}$ danej zbiorowości konwencji nie podlega aprobacie (jest objęta tabu) lub przynajmniej oceniana jest jako gorsza (aprobowana w mniejszym stopniu)" (Grochowski 1995:19). Por. Dąbrowska 1990, Lewinson 1999:346.

4 Tego rodzaju nazwy zwykło się nazywać w lingwistyce „ekspresywami negatywnymi” (Zimnowoda 2005) lub po prostu „wyzwiskami” (Dąbrowska 2009:266, Grochowski 1995:15).

5 Jidysz w dużej mierze opiera się na języku niemieckim, co często utrudnia jednoznaczne wskazanie źródła pożyczek, dotyczy to także słowa bajzel; zob. Brzezina (1986:82-83, 414-415); por. Wswo, ESJPBAŃ. 
XX wieku, podają: JzUŁ, STGP (tu także bajzelek), SAKAN, natomiast jako słowo wulgarne, o takiej samej semantyce, należące do polszczyzny potocznej wymieniają: Spo, Ssiw, Ssp, SpPIw, Spp, SGw, a także słowniki ogólne - historyczne i współczesne: SLeHr, SJPDOR (wulg.), USJP (posp.), WSJP (wulg.); por. bajzelmama 'prostytutka' - StgP, 'właścicielka domu publicznego' - SPP, SPPIw, STgP, Ssiw, USJP (posp.), WSJP (wulg.), bajzelówka 'prostytutka' - Ssıw;

- jatka 'dom nierządu' (SMzKur, SzwEsTr, ŻMPLudWA) - to dziewiętnastowieczny neosemantyzm socjolektalny, oparty na zawężeniu znaczenia, wszak w historycznych i współczesnych słownikach ogólnych polszczyzny odnosi się do szopy, straganu w ogóle: 'chać, kuczka, jakiekolwiek schronienie od powietrza, budka' - L, 'chata, chałupa chłopska, prowincjonalnie: szopa' - SWIL, 'miejsce uboju bydła, rzeźnia' - SJPDor (daw.), 'kram, sklep z mięsem' - SJPDor, 'budka z mięsem' - USJP (daw.), 'w Polsce średniowiecznej: kram na placu targowym' - WSJP (etymologicznie słowo wiąże się z zach. psł. *jatzka 'mała przenośna budka, mały szałas, namiot'); w omawianym znaczeniu wyrazu nie notują ani słowniki socjolektalne (StGP, SAKAN, SGS, SGU), ani opracowania poświęcone słownictwu obscenicznemu (Spo, Ssiw, SsP, SpPIw), ani też leksykony dotyczące polszczyzny potocznej (SPP, SGW);

- majdan 'dom nierządu' (ŻMPLudWA) - to określenie znane polszczyźnie od XVII wieku (wywodzi się z osm.-tur. maydan 'publiczny plac; wolna przestrzeń, otwarty, równy teren; miejsce wydarzeń' i w języku polskim pojawiło się za pośrednictwem języka ukraińskiego bądź kazachskiego: majdan [майдан] ESJPBAŃ [zob. Aqtay/Jankowski 2011:318, Rytter 1992:27]), ale nie w znaczeniu obecnym na gruncie socjolektu przestępczego - słowniki ogólne języka polskiego podają zwłaszcza znaczenia podstawowe, a wśród wtórnych nie pojawia się sens 'dom nierządu': 'plac czworogranny w mieście jakim, plac w fortyfikacji, plac fabryki, budowli' - L, 'plac publiczny, rynek, równina, gdzie można budować, $\mathrm{w}$ twierdzy miejsce, plac wałami otoczony, w obozie miejsce z czterech stron namiotami zabudowane, przechody między namiotami, też miejsce, gdzie się wyrabia drzewo na budulec, warsztat, fabryka' - SWIL, 'plac publiczny, na którym odbywa się sprzedaż czegoś, plac obozowy otoczony namiotami, miejsce w twierdzy otoczone wałami; w ogóle plac otoczony czymś, ogrodzony, wycięty wśród lasu, miejsce w lesie, gdzie się pędzi smołę, terpentynę, dziegieć itp.' - SW, SLeHr, 'plac we wsi, w obozie wojskowym, warowni, dawniej także w mieście; dziedziniec, podwórze' - SJPDor, 'plac we wsi, w obozie wojskowym lub w warowni' - USJP (daw.), 'plac na terenie wsi lub miasta albo między zabudowaniami tworzącymi jakiś zespół' (daw.) - WSJP; w omawianym sensie wyrazu nie notują słowniki socjolektalne (StGP, SAKan, SGS, SGU, jako słowo historyczne podaje JzUŁ), opracowania poświęcone słownictwu obscenicznemu (Spo, Ssiw, Ssp, SPPIw) i polszczyźnie potocznej (SPP, SGW), a to przemawia za tym, by określenie uznać za historyzm socjolektalny, neosemantyzm należący do mowy przestępczej. 


\subsection{Analiza - nazwy „kobiet lekkich obyczajów”}

Grupę określeń kobiet świadczących usługi seksualne, źle prowadzących się, tworzy dwadzieścia dziewięć leksemów (w tym pięć jest wariantami trzech nazw). Ich omówienie warto rozpocząć od zwrócenia uwagi na wyrazy zapożyczone, związane ze złodziejskim jidysz lub rosyjskim żargonem przestępczym. Są to:

- binia 'prostytutka' (ŻzUDZ, SzwEsTr, KPLJAW, ŻMPLUDWA) - określenie znane w Galicji, przy czym było ono używane także w znaczeniu neutralnym: 'dziewczyna, kobieta', o czym informują JzEstr(A), GzEstr, SzwEstr, SMzKuR, KPLJAW; trzeba dodać, że w opracowaniach objętych ekscerpcją odnotowano wiele wyrazów pokrewnych: binios 'pan' (SzwEstr) / binos 'pan, wyelegantowany panicz' (JzEstr(A), GzEstr, SzwEstr), biniosa 'pani' (SzwEstr) / bienioska 'ts.' (SzwEstr) i biniawka 'kochanka, czasem żona' (JzEstr(A), GzEsTR, SzwEstr, ŻMPLUDWA); prawdopodobnie jest to pożyczka z niemczyzny, a w zasadzie z Rotwelsch: niem. Biene (średniowysokoniemieckie bin) - sens prymarny: 'pszczoła' $\leftarrow$ znaczenie wtórne: 'dziewczyna, młoda kobieta' $\leftarrow$ znaczenie wtórne 'prostytutka', jid. bin [ויב] 'pszczoła'(Günther 1914:42-43); wyrazu w ogóle nie notują słowniki ogólne polszczyzny; obecność słowa w mowie przestępców w XIX i XX wieku potwierdzają Gw, SGw, STGP (STGP notuje też formy: bienia, bieniawka, biniawka, ponadto w STGP i SsIw odnotowano postaci: biniacha i biniocha $)^{6}$;

- nafke 'kobieta lekkich obyczajów' (ŻMPLuDWA) - wyraz nienotowany ani w słownikach ogólnych polszczyzny (historycznych i współczesnych), ani też w późniejszych opracowaniach dotyczących socjolektów (JzUŁ podaje go jako słowo wymarłe); określenie zostało przejęte przez język przestępców z polskiego jidysz, w którym nafke [הקפנ] to 'nierządnica' (Grzegorczyk 1924:46, zob. Małocha 1994:141,145) (wyraz znany też w Rotwelsch [Günther 1910:233]); inne opracowania, w tym historyczne i współczesne słowniki ogólne, nie notują określenia, a w JzUŁ pojawia się ono jako dawne, już nieużywane;

- babustyna 'kochanka' (ŻMPLUDWA) - najpewniej słowo wywodzi się z jidysz: pol. jid. Baleboste / pol. babojste [עטסהָבעלאב] 'pani domu' $(\leftarrow$ pol. jid. Bałabois / pol. balebos [תיבה־לע] 'gospodarz') (Grzegorczyk 1924:13, zob. A. Małocha 1994:145), funkcjonującego również w Rotwelsch i Gaunersprache (Klepsch 2004:318), co zamyka możliwość wywodzenia określenia od znanego polszczyźnie w XVI wieku słowa baba, używanego w sensie wtórnym 'sutener' (zob. Reczek 1968:11); należy więc założyć, że sens 'prostytutka' pojawił się na gruncie socjolektu w wyniku neosemantyzacji; wyraz jako wymarły odnotowuje JzUŁ, nie pojawia się też w żadnym innym słowniku ogólnym czy socjolektalnym, historycznym czy współczesnym;

${ }^{6}$ Wyraz znany także w gwarze lwowskiej; zob. Хобзей/Сімович/Ястремська/Дидик-Меуш (2012:94): „binia - prostytutka [біня] - dziewczyna, która ma kawalera, dziewczyna batiara”. 
- chonte 'kobieta lekkich obyczajów' (ŻMPLuDWA) - wyraz notowany wyłącznie w opracowaniu z 1922 roku, w JzUŁ przytoczony jako słowo już nieużywane, leksem nie występuje też $\mathrm{w}$ dawnych i współczesnych słownikach ogólnych polszczyzny (Małocha 1994:142, 145) (wyraz obecny także w dziewiętnastowiecznym Rotwelsch [Günther 1912:247-348]);

- marucha 'kochanka' (ŻMPLUDWA) - poza JzUŁ wyraz bez poświadczeń $\mathrm{w}$ innych polskich opracowaniach; zapewne jest to pożyczka z ruszczyzny socjolektalnej, w której określenie marucha [марухa] jest poświadczone od połowy XIX wieku: 'kochanka' (SwIF), 'kobieta' (SiwwJ), 'zdeprawowana kobieta' (UJAPM, SwJ), 'kochanka złodzieja, złodziejka' (Bмżт), 'zdeprawowana kobieta, członkini świata przestępczego; prostytutka' (SwiaJ, BM, SżP) (por. maruszij [маруший] 'żeński, kobiecy, dziewczęcy' [SiwwJ], mara [мара] 'kochanka lub żona przestępcy' [BM, SżP] / 'prostytutka' [SżP] / 'dziewczyna' [SżP], maruszka [марушка] 'babina' [SwiAJ, Bм, SżP], marusznik [марушник] 'złodziej zajmujący się wyłącznie okradaniem kobiet, zwłaszcza podczas procesji religijnych, zabaw, robienia zakupów' [Bмżт] / 'kieszonkowiec okradający kobiety podczas uroczystości religijnych' [SwJ, SwiaJ, BM, SżP]);

- kotka 'prostytutka porzucona przez alfonsa' (ŻMPLuDWA) - nazwa potwierdzona w XX wieku przez JZUŁ, SGw, STGP i SsIw (słowniki ogólne podają tylko znaczenie prymarne: 'samica kota'); prawdopodobnie określenie jest kalką z rosyjskich gwar przestępczych, w których koszka [кошка] 'kocica, kotka' potwierdzone jest wcześniej: 'kobieta' (BMżT, SwIAJ, SżP) / 'prostytutka porzucona przez kochanka' (Bмżт, SwiAJ) / 'prostytutka' (BM, SżP) (por. obecne w polskim socjolekcie kot 'kochanek' [SzwEsTR, KPLJAW]/ 'sutener' [STGP]) ${ }^{7}$; zapewne od kotka wywiedzione są inne spotykane na rodzimym gruncie formy: $\boldsymbol{k o t y c h a}$ 'kochanka' (SZwEstr, KPLJAW, ŻMPLUDWA), kocicha 'ts.' (ŻMPLUDWA), kucicha 'ts.' (ŻMPLudWA);

- larwa 'prostytutka' (ŻMPLUDWA) - określenie potwierdzone jako żargonizm w JzUє, Gw i StGP, a jako obscena w SsIw; chociaż pojawia się ono także w rosyjskiej mowie przestępców, to czas udokumentowania jego funkcjonowania na tym gruncie przemawia za tym, że w obu językach pojawiło się niezależnie - w ruszczyźnie socjolektalnej nazwa larwa [лярва] w znaczeniu 'prostytutka' notowana jest w opracowaniach od 1908 roku (Swif, Bmżt, Swiaj, Bm, Sżp), tymczasem z 1903 roku pochodzi świadectwo, że wśród członków polskiego półświatka obecny był frazeologizm stara larwa 'publicznica' (SzwEstr) (co więcej, już w SW, w tomie z 1900 roku, mamy odnotowane znaczenia przenośne 'kobieta nierządna, nierządnica', a w L - 'kobieta rozlazła i niechlujna'); nieza-

\footnotetext{
7 Por. znaczenia wtórne w ruszczyźnie od początku XX wieku: kotka [кошка] 'pomocnica złodzieja lub złodziejka, która zwabia klienta do lokalu, gdzie go ograbia', 'chuda, brzydka dziewczyna', 'pasywna lesbijka' (Квеселевич 2003:362); 'kobieta zajmująca się organizowaniem procederu prostytucji, sutenerka', 'prostytutka', 'mała dziewczyna zajmująca się prostytucją i kradzieżami', 'kobieta źle prowadząca się' (Грачев 2003:443).
} 
leżnie od tego miano związane jest z zawężeniem któregoś z wtórnych sensów słowa larwa, obecnych w XIX wieku w obu językach: 'obraźliwie o kobiecie, do której czuje się niechęć, odrazę' / 'upiór, mara' ( $\leftarrow$ 'jedno z pierwszych stadiów rozwoju owada, kokon');

- szantrapa 'prostytutka' (ŻMPLudWA) - funkcjonowanie określenia w socjolekcie przestępczym i w potocznej polszczyźnie XX wieku poświadczają, czasem w pokrewnym sensie: JzUŁ, Gw, Spo, SKan, Stgp, Spp (obraź. 'z niechęcią o kobiecie'), w tym słowniki ogólne (wcześniejsze nie notują): SJPDoR (wiech. 'obelżywie o kobiecie niechlujnej, niemoralnej'), USJP (pot. posp. 'kłótliwa, niesympatyczna kobieta'); słowo zostało zaczerpnięte z potocznego języka rosyjskiego: szantrapa [шантраna] (zob. notacje w: Ожегов/Шведова 1993, Шанский/Иванов/Шанская 1971), przy czym na gruncie polskim przyjęło dwa sensy - całkowicie skalkowany, potoczny ogólny (i chyba późniejszy niż drugi z podanych): 'kobieta odrażająca swoim wyglądem lub zachowaniem, charakterem' (zob. też Kurzowa 1983:236, Młotek 1989:62, Rieger/Masojć/Rutkowska 2006:380), a także, w mowie przestępczej, zawężony: 'prostytutka' (trzeba przy tym wykluczyć adaptację rosyjskiego słowa socjolektalnego, wszak uwzględnione opracowania dotyczące mowy rosyjskich przestępców z XIX wieku i początkowego okresu następnego stulecia słowa nie notują);

- ćma 'publicznica, kochanka' (SzwEsTR) / 'prostytutka' (ŻMPLuDWA) obecność określenia w drugiej połowie XX wieku potwierdzają: Spo, SAKan, SGw, Stgp, Ssiw (w SAKan, SGw, Ssiw także ćma nocna), w słownikach ogólnych polszczyzny, historycznych i współczesnych, słowo notowane jest w innych znaczeniach; może to być neosemantyzm powstały na rodzimym gruncie (motywowany skojarzeniem czasu aktywności owada i najczęstszej pory pracy prostytutek - nocy, ale też faktu gromadzenia się owadów pod latarniami i częstego miejsca wystawania prostytutek), jednakże nie można wykluczyć oddziaływania ruszczyzny socjolektalnej w pojawieniu się znaczenia, wszak w historycznym rosyjskim żargonie przestępczym molawka [молявка] (dosł. 'ćma', mol' [моль] 'ćma, motyl nocny') to 'dziewczyna prostytuująca się' (SwiAJ, BM, SżP), a nocny motyl / ćma [ночная бабочка] to - od XX wieku - 'prostytutka' (zob. Солганик 2004:33, Никитина 2003:27, Мокиенко/Никитина 2000:43, Квеселевич 2003:20);

- rachla 'kochanka' (SzwESTR) - funkcjonowanie określenia po drugiej wojnie światowej potwierdzają: Gw, Spo, SGS, StgP, Ssıw; zazwyczaj podaje się, że wyraz jest zniekształceniem rzeczownika raszpla 'pilnik', pewniejsze wydaje się jednak wywodzenie nazwy od rosyjskiego rychłyj [рыхлыій] 'człowiek otyły, rozlazły, na którego nieprzyjemnie patrzeć'/ r.ż. rychłaja [рыхлая] ( $\longleftarrow$ 'kruszący się, pęczniejący, rozpadający się' Ł ruszit' [pymumb] 'naruszyć, zburzyć'), być może upowszechnionego przez jidysz (Wexler 1983:229-279), co sugeruje obecność analogicznych wyrazów w słowiańskich dialektach żydowskich, mających pokrewne sensy: ros. rachla [ро́хля] 'osoba ospała, leniwa, apatyczna; kobieta 
odpychająca wyglądem, niedbająca o siebie' (EsRJ), czes. ráchla 'dziewczyna' (Treimer 1937:49, 64), błrus. rochlja [ро́хля] 'kobieta wątła, słaba, apatyczna lub kobieta zaniedbana' / 'brzydka, niechlujna, gruba kobieta' (Шаталава 1975:154), ale też w gwarze lwowskiej ruchla 'stary, brudny, zaniedbany Żyd; Żydówka' (Kurzowa 1983:225-226, 355; Горбач 1983:314) (słowo pewnie jest wynikiem apelatywizacji antroponimu Rachel(a) [jid. לחר, hebr. לחד [Wexler 1987:145] i w jakiejś mierze jest stereotypem onimicznym [Pacuła 2012]).

W zasadzie do zapożyczeń należy zaliczyć także określenie meliniarka 'kochanka' (ŻMPLuDWA), wszakże słowo to - podobnie jak meliniarz - wywodzi się od innego rzeczownika należącego do języka kryminalistów - melina 'nocna kryjówka przestępców' (SW i późn. $)^{8}$, a ten wywodzi się z jidysz. Warto przy tym zauważyć, że obecność wspomnianego leksemu melina odnotowują rosyjskie słowniki socjolektalne wcześniejsze niż rodzime opracowania (w dodatku jako wyraz wieloznaczny $)^{9}$, co może wskazywać na udział ruszczyzny w adaptacji słowa $\mathrm{w}$ polskiej gwarze przestępczej - jeśli nie była ona bezpośrednim źródłem pożyczki, to z pewnością stabilizowała ją w mowie złoczyńców (por. pol. jid. maline [ענילאֵ] 'kryjówka' i ros. jid. mieluna [мелуна] [הנולמ] 'skrytka, tajne mieszkanie'; zob. Brzezina 1986:62, Małocha 1994:141, Wexler 1990:161, Вахитов 2007, Ермакова/Земская/Розина 1999:100-101). Otóż w dawnym rosyjskim socjolekcie kryminalnym malina [малина] to 'mieszkanie złodzieja' (Вмżт, SwJ, SwIAJ, SżP, BM), 'kwatera prostytutki' (Вмżт) i 'miejsce ukrycia złodzieja i jego łupów' (SwIAJ, BM). Nie można przy tym wykluczyć, że na rodzimym gruncie derywaty od melina pojawiły się, by odróżnić użycie słowa jako nazwy osoby od określenia miejsca, z którym ta osoba jest związana ${ }^{10}$ - otóż w ruszczyźnie socjolektalnej malina [малина] ma też sensy 'starsza kobieta, która jest pomocnicą złodziejek i złodziei; partnerka złodzieja’ (SwJ, SwIAJ), które polska gwara przestępcza częściowo przejęła, tworząc słowa pokrewne (znaczeń tych nie ma natomiast jidyszyzm maline, a to przemawia za udziałem ruszczyzny w pojawieniu się / ustabilizowaniu się słowa na gruncie polskiego żargonu). Jako wyraz środowiskowy, wywiedziony z mowy złodziejskiej, mający znaczenia 'osoba ukrywająca rzeczy skradzione, dająca schronienie przestępcom' i 'siedziba złodziei', leksem notują słowniki od początku XX wieku (SW, SJPDor, USJP - tu w postaci meliniara). Trzeba przy tym zauważyć, że sens odnotowywany w słownikach jest

\footnotetext{
8 Współczesne znaczenia słów melina i meliniarz zatraciły istotną cechę semantyczną - odnosze-

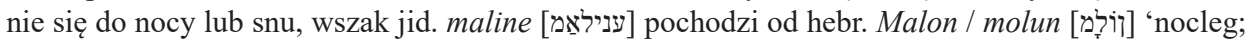
oberża'. Do wspomnianej cechy odnosi się inne słowo obecne w dawnym socjolekcie przestępczym - melińczyk 'złodziej okradający ofiarę po uśpieniu jej narkotykiem'; zachowały ten sem także rosyjskie historyczne żargonizmy - malina [малина] 'miejsce, gdzie można się przespać', malinit' [малинить] 'odurzyć (się) kokainą lub morfiną'.

${ }^{9}$ Rosyjskie opracowania podają cytaty tekstów nawet z pierwszej połowy XIX wieku (zob. omówienia w: Вахитов 2007, Приемышева 2009:394 - 395).

10 W ŻMPLuDWA mamy, obok melina i meliniarka, jeszcze inne słowa: malinować ‘żyć', melinować 'ukrywać' i meliniarz ‘człowiek dający schronienie złodziejom i przetrzymujący skradzione rzeczy'.
} 
nieco szerszy niż podany w źródle objętym ekscerpcją - w późniejszych opracowaniach spotykamy jednak sensy tożsame, choć wyraz przyjmuje inne postaci: meliniara (StGP), melinówa / melinówka (StGP, Ssiw) (Kamler 1991:72).

Zapożyczeniem, tyle że od dawna zaadaptowanym w języku polskim, jest również określenie lupa 'publicznica, kochanka' (SzwEstr) / 'prostytutka' (ŻMPLuDWA). Jako nazwę obecną w socjolekcie przestępczym XX wieku wyraz podają JzUŁ i STGP. Wywodzi się ona od łacińskiego słowa lupa 'wilczyca', w polszczyźnie od średniowiecza używanego przenośnie na nazwanie prostytutki (por. łac. lupanar 'dom publiczny' - w tej postaci także ten wyraz był obecny już w staropolszczyźnie [SsTP]). Zresztą takie miano funkcjonowało już w starożytnym Rzymie i łączyło się z jedną z wersji legend o Remusie i Romulusie. Według niej chłopców wychowała Acca Larentia, żona pasterza Faustulusa, która utraciła majątek zdobyty na uprawianiu nierządu; w późniejszych wersjach legendy chłopcami opiekowała się wilczyca (łac. lupa 'wilczyca') (Schmidt 1996:102-103) stąd znane jeszcze $\mathrm{w}$ antyku utożsamienia: nierządnica $=$ Acca $=$ wilczyca, czyli lupa. Nieuzasadnione jest więc często spotykane wyjaśnienie, że nazwa prostytutki lupa wiąże się z faktem, że ta nocami wabi potencjalnych klientów swoim nawoływaniem, zaczepkami, podobnie jak wilczyca wyciem nawołuje swoje stado.

Do grupy dawniejszych pożyczek, które jednak dopiero na gruncie polskiego socjolektu przyjęły dodatkowe znaczenie, trzeba zaliczyć nazwę szubraczka 'kochanka, przyjaciółka'. Pojawia się ona jeszcze w JzUŁ i STGP (tutaj notowane są także szubracz 'przyjaciel, kochanek' i szubrać / szubrać się 'zmawiać, porozumiewać się, kontaktować się nielegalnie w zakładzie karnym' / 'flirtować, zalecać się'). Określenie łączy się z czes. šubravý 'zbrukany, brudny; nikczemny', wpierw zaadaptowanym przez polszczyznę ogólną w znaczeniu 'łotr, nikczemnik, łachudra' (jako wariant formy szubrawiec, znanej polszczyźnie od XVII wieku, też pochodzącej z czeszczyzny - šubravec 'osoba źle się prowadząca, niemoralna' - L i późn.), następnie - w mowie potocznej i języku kryminalistów - obecnym w zawężonym sensie: 'kochanek, prostytutka' ${ }^{11}$.

Pewne trudności w ustaleniu proweniencji dotyczą określenia gonia 'latawica' (JzEstr(A), GzEstr), którego nie notują żadne słowniki ogólne polszczyzny - zarówno historyczne, jak i współczesne, a spośród opracowań socjolektalnych wymienia go jeszcze JzUŁ. Nazwę można łączyć z polskim gonić (się) 'biec, usiłując kogoś lub coś dopędzić; uganiać się za czymś, kimś' lub gonić się 'potocznie o zwierzętach: odczuwać popęd płciowy' (L, SWIL, SW, SJPDor, USJP, WSJP), a przez to uznać ją za neologizm ('ta, która goni za klientem, oferując usługi seksualne; ta, którą cechuje duży popęd seksualny'); można też wiązać określenie z rumuńskim czasownikiem goni 'biegać; ścigać; prześladować; latać' (Dicţionarul 1913-1940:286, Mihăilă 1960:199); wreszcie można wywodzić na-

11 Szersze omówienie etymologiczne i dyskusję z tym związaną zawierają prace: Lehr-Spławiński (1939), Basaj/Siatkowski (1977). 


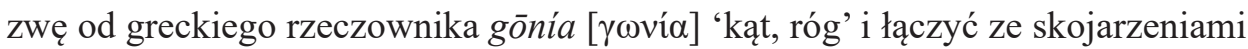
pokątnego uprawiania nierządu, spółkowaniem po kątach lub wystawaniem prostytutek na rogach budynków, ulic. Wydaje się jednak, że pierwsza z hipotez jest najbliższa prawdy - w tej sytuacji byłby to derywat odczasownikowy mutacyjny, a takie formacje występujące $w$ funkcji ekspresywnych określeń kobiet spotykamy w gwarach małopolskich (za tym przemawia także fakt, że źródła - JzEsTR(A) i GzEsTR - podają określenie gunia jako nazwę funkcjonującą właśnie w dawnej Galicji) (por. Marciniak-Firadza 2013:53, 62, 219, 230 - tu: gonia i gonicha 'kobieta uganiająca się za mężczyznami'). Zauważmy przy okazji, że podobne etymologizowanie może dotyczyć także nazwy szlaja 'nierządnica' (SzwEstr) / 'prostytutka' (ŻMPLuDWA) i jej formy deminutywnej - szlajka 'kobieta złego życia' (GzEsTR, SzwEstr) / 'prostytutka' (ŻMPLudWA). W tym przypadku podstawą będzie czasownik szlajać się 'chodzić w jakieś, zwykle podejrzanych, miejsca, włóczyć się’ (Marciniak-Firadza 2013:188), stąd dwa potoczne znaczenia w XX wieku: szerszy - 'niemoralnie się prowadzić' i węższy - 'prostytuować się' (SLeHr, USJP), które stały się źródłem derywatów rzeczownikowych, obecnych w socjolekcie i potocznej polszczyźnie: 'ulicznica, prostytutka' (szlaja: JzUŁ, SaKan, SGw, StgP, Ssiw, SLehr, USJP, szlajka: SGw, StgP, Ssiw).

W zgromadzonym materiale znajduje się dziewięć nazw będących neologizmami strukturalnymi i semantycznymi. Są to:

- poduszka 'kochanka' (ŻMPLUDWA) - określenie bez potwierdzeń w opracowaniach dotyczących socjolektów kryminalnych z drugiej połowy XX wieku (w JzUŁ jest odnotowane jako dawne, w Gw odnotowane w sensie szerszym: 'kobieta'), słowniki ogólne i polszczyzny potocznej podają wyraz w innych znaczeniach; sens obecny w socjolekcie przestępczym jest wynikiem neosemantyzacji - przeniesienie znaczenia opiera się na asocjacjach, hańbiącym porównaniu roli kobiety w związku z funkcją poduszki: w obu przypadkach znajdują zastosowanie w łóżku;

- ścierka 'kobieta lekkich obyczajów' (ŻMPLUDWA) - wyraz notowany w słownikach ogólnych w innych sensach; jako określenie obraźliwe, obecne w socjolektach i potocznej polszczyźnie podają STGP, SsIw (w obu także wariant ściera); nazwa to wynik neosemantyzacji motywowanej połączeniem funkcji przedmiotu przeznaczonego do tarcia, ścierania i usuwania brudu z rolą prostytutki, wykorzystywaniem jej ciała, traktowaniem jej jako kogoś mało wartościowego, przeznaczonego wyłącznie do realizacji „nieczystych” zadań, dającego się zbrukać;

- skówa 'prostytutka' (ŻMPLUDWA) - jedyne potwierdzenie istnienia określenia znajdziemy w SGW opisującym dziewiętnastowieczną gwarę warszawską, przy czym opracowanie podaje wersję skuwa; to sugeruje, że nazwa wiąże się z rzeczownikiem skuwka, jest jego formą augmentatywną, przez co wyraźniej wartościuje, widoczny staje się jej ekspresywny charakter - skuwka / skuwa są przy tym metaforycznym nawiązaniem do kobiecej pochwy, wszak prymarnie oznaczają 'tuleję, cylindryczną nasadkę'; 
- prawiczka 'prostytutka niezarejestrowana' (ŻMPLUDWA) - nazwa przytoczona później wyłącznie w JzUŁ, STGP i SsIw; powstała wskutek uniwerbizacji wyrażenia prawa dziewica, wpierw przyjmując znaczenie kontynuowane do dzisiaj: 'prawa panna, nienaruszona, dziewica' (L) / 'dziewica nieskalana, żyjąca w panieństwie' (SWIL) / 'kobieta, która nie miała stosunku płciowego' (WSJP), a w międzyczasie, w mowie potocznej i języku środowisk dewiacyjnych, zawężając sens do 'prostytutka świadcząca usługi nielegalnie, potajemnie, bez rejestracji' $^{12}$;

- prostodziura 'prostytutka' (ŻMPLUDWA) - określenie potwierdzone w opracowaniach późniejszych: SPO, SAKAN, STGP, SsIw (brak notacji w słownikach ogólnych); może być ono wynikiem kontaminacji dwóch wyrazów: prostytutka i dziura (w sensie przenośnym 'pochwa');

- rogówka 'prostytutka' (ŻMPLUDWA) - nazwa udokumentowana w późniejszych: JzUŁ, SAKAn, SGw, STGP, SsIw (w dwóch ostatnich także w postaci rogówa), bez poświadczeń w słownikach ogólnych; zapewne jest to derywat od rzeczownika róg, mogącego występować w dwóch znaczeniach: 'zbieg ulic lub węgieł budynku' (odnosząc się do miejsca pracy prostytutki, oczekiwania na klientów) lub 'penis' (przenośne nazwanie członka męskiego, motywowane kształtem);

- strychówka 'prostytutka' (ŻMPLUDWA) - określenie przytoczone wyłącznie w JzUŁ i STGP; rzeczownik wywiedziony od strych 'poddasze', odnoszącego się prawdopodobnie do miejsca uprawiania nierządu, lokalu, w którym prostytutka świadczy usługi i - być może - w którym mieszka;

- pikielowa 'prostytutka kontrolna' (ŻMPLUDWA) - słowo bez poświadczeń w innych opracowaniach - zarówno wcześniejszych, jak i późniejszych; można postawić tezę, że nazwa wiąże się z leksemem pikiel 'szpic' - skróconą wersją nazwy hełmu zakończonego na szczycie ostrym grotem, dawniej noszonego przez żandarmów: pikielkhauba, za czym przemawia to, że prostytutki legalnie prowadzące działalność (zarejestrowane) pozostawały pod kontrolą medyczną i stałym nadzorem żandarmerii ${ }^{13}$;

\footnotetext{
12 W części ziem pozostających pod zaborami prostytucja nie była poddawana kontroli władz, ale na przykład w Cesarstwie Rosyjskim, a więc i w Kongresówce, zalegalizowano domy publiczne, a prostytutki zobowiązano do rejestracji w specjalnie zorganizowanych komitetach policyjno-lekarskich. Szerzej zob. Sikorska-Kulesza (2004, zwł. 103-154), Karpiński (2010).

13 Zob. między innymi artykuły Sylwii Kuźmy-Markowskiej „Wiele twarzy »nierządu«. Prostytucja w międzywojennym Wilnie” (2013:291-309) („Wprowadzony w Drugiej Rzeczypospolitej system neoreglamentacyjny likwidował domy publiczne i powoływał urzędy sanitarno-obyczajowe do nadzoru nad »nierządem «, tym samym definiując prostytucję jako przede wszystkim problem sanitarny i prowadząc do jej medykalizacji. Prostytutki legalne, postrzegane jako potencjalne źródło chorób wenerycznych, były zobowiązane do posiadania książeczek oraz zgłaszania się na kontrolę lekarską dwa razy w tygodniu”. [291]) oraz Mateusza Rodaka „Prostytucja w Lublinie w dwudziestoleciu międzywojennym" (2007:379-390).
} 
- wytyczka / wytyżka 'młoda prostytutka' (ŻMPLUDWA) - słowo bez poświadczeń we wcześniejszych i późniejszych opracowaniach i leksykonach; można by szukać związku określenia z sensem notowanym w słownikach historycznych: wytyczka 'zarzut' (L i późn.), można też próbować wiązać nazwę z innymi jednostkami słownikowymi obecnymi w dawnym żargonie przestępczym: wytyczny 'uciekinier', robić wytyki 'uciekać', jednak najpewniejsza, bo bliska czasowo omawianemu określeniu, wydaje się teoria zaprezentowana w artykule prasowym w „Expressie Wieczornym Ilustrowanym” z 27 marca 1927 roku:

Przedmiotem nienawiście dziewcząt, oddających się nierządowi, są t. zw. „wytychy”. Etymologia tego słówka, utartego w żargonie ulicy, trudna jest do ustalenia. Nie pozbawiona będzie słuszności hipoteza, że pochodzi ono od dziwolągu urzędowego słownictwa - 'wytycz', co ma oznaczać kobietę 'wytyczoną' do reglamentacji, podejrzaną o pokątne, że się tak wyrazimy, uprawianie nierządu, którą mają na oku agenci policji obyczajowej. Pewnego dnia dziewczyna taka zostaje przyłapana przez agenta w jakimś hotelu i doprowadzona do zbadania do urzędu sanitarno-obyczajowego, gdzie w razie stwierdzenia choroby wenerycznej, rejestrują ją i wysyłają na kurację do szpitala. Tu się kończy karjera t. zw. 'wytyczki', która ujęta w żelazne karby reglamentacji i dotkliwe 'prawo puszczy', obowiązujące śród mętów ulicy znosi aż do kresu twardą dole prostytutki. Historja 'wytyczki' jest szablonowa aż do znudzenia. [...] Ze szkoły i z domu rodzicielskiego, który opuszcza w młodym b. wieku, wynosi resztki idealizmu. [...] W chwilowych związkach szuka rozrywki miłości i staje się ofiarą 'złotych młodzieńców', których podbija swoją bezinteresownością. Potrzeby dnia codziennego zabijają w niej tą bezinteresowność, za którą nienawidzą ją jej zawodowe koleżanki. [...] Częste przeto są wypadki denuncjonowania 'wytyczek' przez zawodowe prostytutki. Zadenuncjonowana musi przejść przez czyściec szpitala. Za wrotami szpitala czeka na nią dokument hańby - czarna książka, ostateczny patent akademji nierządu. Po kilku miesiącach niczem nie różni się od zwykłej prostytutki (Bezlitosne 1927:4; zachowano pisownię oryginału).

\subsection{Analiza - nazwy „opiekuna” prostytutek}

W źródłach objętych ekscerpcją znaleziono sześć określeń osób sprawujących pieczę nad działalnością prostytutek i czerpiących zyski z uprawianego przez nie nierządu. Łatwo przy tym zauważyć, że zgromadzone miana często odnoszą się nie tylko do osób zajmujących się sutenerstwem, ale też oznaczają życiowych partnerów prostytutek. Wynika to z powszechnego w XIX wieku i w początkach następnego stulecia kuplerstwa i stręczycielstwa, które doprowadziły do tego, że do dziś wśród osób żerujących na czyjejś prostytucji wyróżnia się „typ opiekuna” 
(żyje i mieszka z jedną prostytutką, chroni ją przed organami władzy, niekiedy są oni ze sobą związani uczuciowo), „typ wyzyskiwacza” (czerpie zyski z eksploatacji kilku prostytutek, ułatwia im nawiązywanie kontaktów) i „typ wspomagacza” (dysponuje lokalami do wynajęcia, prowadzi potajemny dom schadzek) (Lernell 1974:424, Imieliński 1980:56-57).

Prezentację materiału leksykalnego warto rozpocząć od określeń bodaj najpopularniejszych, bo znanych również współcześnie, choć nie zawsze ich użytkownicy zdają sobie sprawę z ich pochodzenia ${ }^{14}$. To nazwy alfons i luj.

Pierwszemu z przywołanych leksemów - alfons - w źródłach objętych ekscerpcją przyporządkowano takie same wyjaśnienia: opracowanie z XIX wieku podaje sens 'opiekun prostytutek z niemi mieszkający' (SzwEsTR), z kolei tekst $\mathrm{z}$ drugiej dekady XX wieku odnotowuje znaczenie 'opiekun prostytutki będący jednocześnie jej kochankiem' (ŻMPLuDWA). Jeśli spojrzymy do słowników ogólnych polszczyzny, zauważymy, że pierwszy raz słowo we wtórnym znaczeniu przytacza SJPDor: 'mężczyzna utrzymywany przez prostytutkę' (tutaj też alfonsiak z informacją (wiech.), w USJP - posp. 'sutener', tu także forma alfonsiak z kwalifikatorem (pogard.), w WSJP - pot. pogard. 'sutener'). Czas pojawienia się w słownikach sekundarnego sensu pozwala założyć, że określenie jest efektem apelatywizacji antroponimu Alfons - imienia noszonego przez bohatera powieści Aleksandra Dumasa z 1873 roku Monsieur Alphonse, wszak ta tytułowa postać trudniła się właśnie sutenerstwem (por. Michalewski 1972:101-131). Nazwa własna szybko stała się potocznym synonimem sutenera, na co wskazuje jej obecność we francuskich opracowaniach z końca XIX wieku, które potwierdzają literacki źródłosłów (zob. na przykład Delesalle 1896:9, Virmaître 1894:9, Hayard 1907:7). To zaczerpnięte $\mathrm{z}$ francuszczyzny socjolektalnej określenie na dobre zaadaptowało się w języku polskim, czego wyrazem są notacje słowa alfons nie tylko w słownikach ogólnych, lecz także w innych opracowaniach: poświęconych gwarom przestępczym - JzUŁ, SAKAN, STGP (w dwóch ostatnich także alfonsiak), odnoszących się do polszczyzny potocznej i gwar miejskich - SpP, SpPIw, SGW (tu też alfonsik), a także opisujących polski język erotyczny - SsIw, SsP.

Z nazwą własną łączy się także określenie luj 'sutener' (ŻMPLudWA). I w tym przypadku należy sięgnąć do historycznych opracowań francuskich, które rejestrują dziewiętnastowieczny argot, by dowiedzieć się, że Louis (pol. Ludwik) to 'właściciel domu publicznego' i 'prostytutka mająca swojego opiekuna' (Delesalle 1896:166). Wobec tego forma luj byłaby odwzorowaniem wymowy imienia: [lu.i]. Nieprawdziwe są więc spotykane niekiedy w rodzimych opracowaniach teorie na temat pochodzenia słowa: rzekomo ma być ono efektem kontaminacji lać 'oddawać mocz' i chuj 'członek' albo ma się łączyć z francuskim antroponimem Jules (owszem, współczesny żargon francuski dysponuje słowem jules w sensie 'sutener', ale historyczna perspektywa oglądu zagadnienia nakazuje

14 Być może jest tak dlatego, że obecnie częściej używa się tych słów jako wyzwisk, na przykład alfons - pot. pogard. 'mężczyzna, do którego mówiący ma negatywny stosunek' (Wssp). 
odrzucić związek słowa luj z Jules / jules [te bardziej sugerują związek z żul]). Jeśli zaś chodzi o obecność określenia w polszczyźnie, to w XX wieku notują je (w znaczeniu 'sutener, stręczyciel') JzUŁ, SGW, StGP, SaKan.

Nazwa kot 'kochanek' (SzwEstR, KPLJAW), 'opiekun prostytutki będący jednocześnie jej kochankiem' (ŻMPLuDWA) tylko pozornie jest określeniem rodzimym. Jeśli bowiem uwzględni się fakt, że na rodzimym gruncie pojawiła się ona później niż w mowie rosyjskich przestępców, to trzeba uznać, że najpewniej jest to pożyczka. Przemawia za tym również to, że polskie opracowania opierają się na informacjach (informatorach i źródłach pisanych) pochodzących ze wschodnich terenów Polski, gdzie oddziaływanie ruszczyzny (także socjolektalnej) było bardzo silne. W żargonie rosyjskich przestępców z XIX wieku i pierwszych dziesięcioleci następnego wieku znajdziemy bowiem miano kot [Kom] 'złodziej żyjący z zarobku swojej kochanki uprawiającej prostytucję' (Bмżт) / 'pomocnik złodziejki, czerpiący zyski z jej działan' (SwJ) / 'kochanek prostytutki, jej wspólnik' (SwJ, BM, SżP) / 'kontroler, opiekun złodziejki lub prostytutki' (SżP). Jego istnienie w polskim socjolekcie powojennym potwierdzają JzUŁ i STGP (w obu 'sutener'). Dodajmy jeszcze, że na gruncie socjolektu rosyjskiego zoomorfizm kot w sensie 'sutener' pojawił się w wyniku neosemantyzacji (taki wniosek można wyciągnąc na podstawie zestawienia definicji obecnych w historycznych słownikach): kot 'zwierzę' Ł 'mężczyzna pożądliwy, rozpustny; mężczyzna, który wykazuje większe zainteresowanie kobietami, kobieciarz' $\leftarrow$ 'sutener' 15 .

Do omawianej subkategorii słownictwa należą także neologizmy. Pierwszy z nich - przydupnik 'opiekun prostytutki będący jednocześnie jej kochankiem' (ŻMPLUDWA) - spotkamy jeszcze w JzUŁ i STGP. Mogłoby się wydawać, że miano jest derywatem powstałym od wyrażenia przy dupie, w którym dupa to 'kobieta; prostytutka', jednak historyczne słowniki rejestrujące język półświatka nie odnotowują słowa dupa z takim metaforycznym sensem (pojawił się on później). Można zatem założyć, że jest to neosemantyzm socjolektalny oparty na przesunięciu znaczenia, wszak prymarnie - jak wynika z notacji w SW - słowo było ogólnym określeniem mężczyzn zbyt nadskakujących kobietom. Późniejsze opracowania albo odnotowują tylko podobną formę wyrazową - przydupas - wraz ze znaczeniami 'sługus' i 'wulgarne określenie kochanka' (USJP, WSJP), albo traktują - jak zasygnalizowano, nie do końca zasadnie - postaci przydupnik i przydupas jako ekwiwalenty utworzone za pomocą różnych formantów (na przykład STGP oba słowa podaje jako synonimiczne odpowiedniki wyrażenia dupa karmiony, wszystkim

\footnotetext{
15 Znaczenia wtórne pojawiają się dopiero na przełomie XIX i XX wieku - kot [kom]: 'włóczęga, oberwaniec' (1903), 'chuligan' (1914) (Филин 1979:100); 'konduktor w wagonie kolejowym', 'stały bywalec więzienia', 'brudny, zaniedbany mężczyzna', 'złodziej działający na rynku', 'mężczyzna kierujący się pożądaniem seksualnym', 'sutener', 'kochanek prostytutki, jej utrzymanek' (Грачев 2003:440); 'ten, który żyje ze środków uzyskanych przez swoją kochankę-prostytutkę; alfons', ‘stały klient bazaru', 'miejscowy więzień' (Квеселевич 2003:360); 'sutener' (Шахматов/ Чернышёв 1956:1533).
} 
jednostkom przyporządkowując sensy: 'sutener', 'sługus, pachołek', 'ukochany, narzeczony', a SpPIw podaje: przydupas [posp./wulg., pogard.] 'osoba komuś podporządkowana i działająca na jego rzecz').

Kolejnym określeniem jest maciornik 'opiekun prostytutki będący jednocześnie jej kochankiem' (ŻMPLudWA) / ‘utrzymujący dom publiczny' (ŻMPLuDWA). Chociaż miano to jako należące do języka przestępców poświadczone jest dopiero w opracowaniu z 1922 roku, to już w połowie XIX stulecia w słowniku Mrongowiusza przeczytamy: „Hurentwirth [...] Rufijan ober Kurwigospodarz [...], maciornik bordelu | Hurenwirthinn [...] maciora (bordelowa)" (Mrongowiusz 1823:335, 675), z kolei SW w tomie drugim z 1900 roku odnotowuje dwa sensy: 'mąż maciory' i - wtórny, potoczny - 'utrzymujący dom publiczny, burdelnik, makarelnik, kurwigospodarz'). W późniejszych latach, ale jako słowo wulgarne lub należące do mowy kryminalistów, wyraz poświadczają: JzUŁ, StgP i Ssiw (w dwóch ostatnich opracowaniach znajdziemy dodatkowo: maciora 'właścicielka domu publicznego' STGP / 'prostytutka' STGP, Ssiw, maciornica 'ts.' STGP, SsIw). Można zatem przyjąć, że nazwa maciornik to neologizm semantyczny: 'kochanek prostytutki lub jej opiekun' $\leftarrow$ 'partner świni lub innego zwierzęcia rozpłodowego' (por. maciora - od staropolszczyzny wyraz oznacza przede wszystkim matkę [SsTP], a w różnych okresach polszczyzny odnosił się też do opiekuna, zwierzchnika i przywódcy: 'matka; samica między ptakami i zwierzętami; matka pszczół; u świni samica, u dzików samica od dzieci' - L, 'matka, rodzicielka; samica u zwierząt, gdy ciężarna, lub płodna, szczególniéj mówiąc o świni; królowa pszczół' - SWIL, 'matka; samica u zwierząt, płodna lub ciężarna, szczególnie mówiąc o świni; matka, królowa pszczół' - SW, 'samica u zwierząt płodna lub ciężarna, szczególnie w odniesieniu do świni' - SLEHR, 'samica świni lub dzika' - SJPDor, USJP, WSJP).

Wśród ekscerptów znalazło się także określenie brat polski 'opiekun prostytutek z niemi mieszkający' (SzwEstr). Dotarcie do jego źródła i odkrycie jego motywacji jest dosyć skomplikowane, a wnioski tego dotyczące muszą pozostać w sferze hipotez. Przyczyna tkwi w tym, że żadne opracowania - ani wcześniejsze, ani późniejsze - wyrażenia nie notują, a co więcej, w źródłach odnotowane jest tylko raz (w opracowaniu z 1903 roku). Można je jednak znaleźć w dawnej batiarskiej gwarze lwowskiej: tutaj brat polski to tyle co 'swojak, swój chłop, morowy człowiek', bliskoznacznik nazwy batiar / baciar 'ulicznik, łobuz'; tak przynajmniej wynika między innymi z kontekstu pojawienia się sformułowania $w$ jednej z lwowskich przyśpiewek ulicznych z około 1905 roku o batiarze Jóźku Marynoskim oraz opowiadania Zapolskiej z 1911 roku o życiu lwowskiej kołtunerii:

Komuż to graju?/ Komu śpiwaju?/ Marynoskiemu,/ bratu polskiemu.// Un płaci szóstakami/ i korunami,/ i guldynami,/ w końcu kułakami ${ }^{16}$ (przyśpiew-

\footnotetext{
${ }^{16} \mathrm{~W}$ triadzie koruny - guldyny - kułaki chodzi o nazwy pieniędzy o różnej wartości, układ odzwierciedla siłę pięści.
} 
ka anonimowa z około 1905 roku, nawiązująca do Ballady o dezerterze Jóźku Marynowskim; cyt. za: Habela/Kurzowa 1989:85-87).

W przedpokoju czeka nowy stróż. Wyraźny typ łyczakowskiego rzezimieszka. W Paryżu, ten genre młodzieży zowie się les apaches, po naszemu, jako wyrób krajowy - polski brat, po łyczakowsko-lwowsku - Batiar. Cechy są wspólne: spanie pod gołem niebem i nóż za cholewą. Czasem, dla ukrycia się przed policyą - zajęcie posady kanalarza lub stróża u właścicielek, będących jeszcze w rozterce co do pojmowania równości praw tak zwanych ludzi. Chlebodawczynie tego rodzaju (gdyż celują w tem kobiety) czują wszakże, iż dają mało - żądają więc też mało. Nowy stróż Teodor w kamienicy Dulskiej zadawalnia się jamą koło „ustępów”, dając wzamian jako swą jaźń duchową takąż kałem zionącą jamę (Zapolska 1911:67).

Przy takim założeniu należy uznać, że w języku półświatka określenie brat polski zaadaptowało się jako żartobliwe nazwanie kogoś bliskiego prostytutce, czyli jej opiekuna, kochanka, sutenera.

\section{Tytułem zakończenia}

Łatwo zauważyć, że w zbiorze wyekscerpowanych jednostek należących do kategorii tematycznej ,prostytucja” przeważają ekspresywne nazwania człowieka. Co ciekawe, mimo że samo zagadnienie uprawiania nierządu w świecie pozaprzestępczym wartościowane jest ujemnie, to słownictwo używane przez członków półświatka już takiej oceny jednoznacznie nie wyraża - nie można powiedzieć, by było ono szczególnie wulgarne, negatywnie nacechowane, wyraźnie wyrażające ich ujemny stosunek do kwestii nierządu. Mogłoby się wydawać, że skoro badane słowa należą do rejestru leksyki przestępczej, to słownictwo ze sfery erotycznej będzie bardziej dosadne, wulgarne, a tymczasem wcale tak nie jest: mamy za to drwinę, żart i presupozycje, które tę ,plugawość” języka zastępują. Potwierdza to wyrażone we wstępie artykułu przekonanie, że sfera erotyki objęta jest tabu również w środowiskach dewiacyjnych, jednakże jego źródeł należy upatrywać nie tyle w przyzwoitości, skromności mówiących czy ich dezaprobacie lub odrazie dla zjawiska prostytucji (przecież sami niejednokrotnie uczestniczyli w różnych rolach w procederze nierządu), ile w poczuciu wstydu czy poczuciu winy. Można zatem powiedzieć, że w środowisku przestępczym detabuizacji poddany jest temat seksualności człowieka (tabu w planie treści raczej nie istnieje - mnogość słownictwa jest tego najlepszym dowodem), ale nie sposób mówienia o tym (plan wyrażania). Inna sprawa, że wśród określeń osób dominują feminatywa - co ciekawe, są to wyłącznie nazwy „kobiet lekkich obyczajów”, nigdy „opiekunów" prostytutek, właścicielek domów publicznych, a przecież dawniej wiele 
domów schadzek prowadziły właśnie kobiety. Bardziej uprzywilejowana pozycja mężczyzn znajduje odzwierciedlenie także w tym, że semantyka ich określeń nie jest aż tak wyraźnie pejoratywizowana, jak nazewnictwo kobiet (zob. Peisert 1994:97-119). Być może wszystko to ma związek z faktem, że przestępczość była (i jest) domeną mężczyzn, a udział kobiety w funkcjonowaniu półświatka sprowadzał się do pomagania mężczyznom, służenia im, spełniania ich potrzeb.

Jeśli chodzi o źródła przywołanych nazw należących do kategorii ,prostytucja”, to dominują tu pożyczki. Ze względu na to, że w socjolektach przestępczych należących do różnych języków sposób kategoryzowania rzeczywistości pozajęzykowej, ujmowania jej fragmentów poprzez metafory jest niezwykle zbliżony, to wiele określeń okazuje się podobnych lub takich samych. To z kolei czasami utrudnia jednoznaczne stwierdzenie, czy dane miano jest rezultatem neosemantyzacji, która dokonała się na rodzimym gruncie, czy też jest ono kalką z obcych gwar przestępczych. Zazwyczaj sprawę ułatwiają kwerendy historycznych opracowań odnoszących się do języka złoczyńców, ale niekiedy bywa to niewystarczające i teorie związane z proweniencją jakiejś nazwy muszą pozostać w sferze hipotez. Inna sprawa, że takie drobiazgowe przeszukiwania obcojęzycznych tekstów poświęconych mowie przestępców z XIX wieku może doprowadzić - jak ma to miejsce w niniejszym artykule - do sprostowania omyłek spotykanych w polskich opracowaniach i często powielanych przez innych autorów oraz do uzupełnienia luk dotyczących etymologii jakichś określeń bądź dodania czegoś do istniejących już komentarzy.

Okazuje się, że badanie środowiskowych odmian polszczyzny w perspektywie diachronicznej jest potrzebne, bo rzuca nowe światło nie tylko na słownictwo socjolektalne używane współcześnie, lecz także na potoczną odmianę polszczyzny - jak wskazują analizy, większość słów nadal funkcjonuje w gwarach przestępczych, spora ich część odnotowywana jest również w słownikach języka młodzieżowego, niektóre na dobre zaadaptowały się w polszczyźnie ogólnej (zwłaszcza mówionej), pełniąc funkcję eufemizującą (zob. notacje w: Dąbrowska 1998, Kociemba-Żulicka 2011). Jeszcze ciekawsze spostrzeżenia przynosi opis leksyki dotyczącej sfery intymnej człowieka, życia seksualnego, wszak zagadnienia te - przez długi czas omijane w pracach językoznawczych - są obszarem szczególnie bogatym w materiał, a wnikliwa jego obserwacja pozwala na stawianie nowych tez i weryfikację teorii już istniejących.

\section{Rozwinięcie skrótów zastosowanych w tekście}

$\mathrm{BM}$

- Блатная музыка. Словарь жаргона преступников. Издание управления уголовного розыска республики, 1923, Москва. (Blatnaâ muzyka. Slovar' žargona prestupnikov. Izdanie upravleniâugolovnogo rozyska respubliki, 1923).

Вмżт - Трахтенберг Василий Ф., 1908, Блатная музыка (,жаргон” тюрьмы), Санкт-Петербург. (Trahtenbergvasilij F., 1908, Blatnaâ muzyka (,„̌argon” tûr'my), Sankt-Peterburg). 
ESJPBAŃ - Bańkowski Andrzej, 2000, Etymologiczny słownik języka polskiego, t. 1-3, Warszawa.

ESRJ - Фасмер Макс Ю. Ф., 1964-1973, Этимологический словарь русского языка. Т. 1-4, Москва. (Fasmer Maks Û. F., 1964-1973, Ėtimologičeskij slovar' russkogo âzyka. T. 1-4, Moskva).

Gw - Wieczorkiewicz Bronisław, 1968, Gwara warszawska dawniej i dziś, Warszawa.

GzEstr - Estreicher Karol, 1867, Gwara złoczyńców, Warszawa.

JzEstr(A) - Estreicher Karol, 1859, Język złoczyńców, w: Rozmaitości. Pismo dodatkowe do Gazety Lwowskiej 12, s. 89-92.

JzEstr(в) - Estreicher Karol, 1859, Język złoczyńców, w: Rozmaitości. Pismo dodatkowe do Gazety Lwowskiej 13, s. 97-100.

JzUŁ - Ułaszyn Henryk, 1951, Język złodziejski, Łódź.

KPLJAW - Jaworskij Juljan, 1901, Kumać po lembersku. Przyczynek do słownika lwowskiej gwary złodziejskiej, w: Lud 7, s. 276-281.

L - Linde Samuel B., 1807-1814/1854-1860, Słownik języka polskiego, t. 1-6, Lwów.

SAKAN - Kania Stanisław, 1995, Słownik argotyzmów, Warszawa.

SGW - Wieczorkiewicz Bronisław, 1966, Słownik gwary warszawskiej XIX wieku, Warszawa.

Siwws - Смирнов Николай Н., 1899, Слова и выражения воровского языка, выбранные из романа вс. Крестовского „петербургские трущобы”, Санкт-Петербург. (Smirnov Nikolajn., 1899, Slova i vyraženiâ vorovskogo âzyka, vybrannye iz romana vs. Krestovskogo ,peterburgskie truŝoby”, Sankt-Peterburg).

SJPDor - Doroszewski Witold (red.), 1958-1969, Słownik języka polskiego, t. 1-11, Warszawa.

SLehr - Lehr-Spławiński Tadeusz (red.), 1939, Trzaski, Everta i Michalskiego słownik języka polskiego, t. 1-2, Warszawa.

SmzKur - Kurka Antoni, 1899, Słownik mowy złodziejskiej, Lwów.

Spo - Kiełbasa Stanisław, 1978, Dictionary of Polish Obscenities, Buffalo.

SpP - Anusiewicz Janusz, Skawiński Jacek, 1996, Słownik polszczyzny potocznej, Warszawa/Wrocław.

SpPIW - Grochowski Maciej, 1995, Słownik polskich przekleństw i wulgaryzmów, Warszawa.

Ssiw - Tuftanka Urke, 1993, Zakazane wyrazy. Słownik sprośności i wulgaryzmów, Warszawa.

Ssp - Lewinson Jacek, 1999, Słownik seksualizmów polskich, Warszawa.

SSTP - Urbańczyk Stanisław (red.), 1953-2002, Słownik staropolski, t. 1-11, Warszawa/ Wrocław/Kraków.

StGP - Stępniak Klemens, 1993, Słownik tajemnych gwar przestępczych, Londyn.

SW - Karłowicz Jan, Kryński Adam, Niedźwiedzki Władysław, 1900-1927, Słownik języka polskiego, t. 1-8, Warszawa.

SwIAJ - Попов Всеволод M, 1912, Словарь воровского и арестантского языка, Киев. (Роpov Vsevolodm, 1912, Slovar' vorovskogo i arestantskogo âzyka, Kiev).

SwIF - Собрание выражений и фраз, употребляемых в разговоре с петербургскими мошенниками, 1859, w: Северная пчела 282, s. 1129-1130. (Sobranievyraženij i fraz, upotreblâemyh v razgovore s peterburgskimi mošennikami, 1859, w: Severnaâ pčela 282, s. 1129-1130).

SWiL - Zdanowicz Aleksander, Michał Szyszko-Bohusz, 1861, Słownik języka polskiego, t. 1-2, Wilno.

SwJ - Лебедев Василий, 1909, Словарь воровского языка, w: Вестник полиции 22, s. 456-458 / 23, s. 477-478 / 24, s. 499-500. (Lebedev Vasilij,1909, Slovar' vorovskogo âzyka, w: Vestnik policji 22, s. 456-458 / 23, s. 477-478 / 24, s. 499-500).

SzwEstr - Estreicher Karol, 1903, Szwargot więzienny, Warszawa.

SżP - Потапов Сергей M., 1927, Словарь жаргона преступников, Москва. (Potapovsergej M., 1927, Slovar' žargona prestupnikov, Moskva). 
UJAPM - Путилин, Иван Д., 1904, Условный язык петербургских мошенников, известный под именем „Музыки” или „Байкового языка”, w: Записки И.Д. Путилина. Том 4, Санкт-Петербург, s. 261-267. (Putilin, Ivan D., 1904,Uslovnyj âzyk peterburgskih mošennikov, izvestnyj pod imenem „Muzyki” ili „Bajkovogoâzyka”, w: Zapiski I.D. Putilina. Tom 4, Sankt-Peterburg, s. 261-267).

USJP - Dubisz Stanisław (red.), 2003, Uniwersalny słownik języka polskiego, t. 1-6, Warszawa.

WSJP - Żmigrodzki Piotr (red.), 2007-, Wielki słownik języka polskiego, Kraków.

Wswo - Bańko Mirosław (red.), 2008, Wielki słownik wyrazów obcych PWN, Warszawa.

ŻMPLuDWA - Ludwikowski Wiktor, Walczak Henryk, 1922, Żargon mowy przestępców. „Błatna muzyka". Ogólny zbiór słów gwary złodziejskiej, Warszawa.

ŻzUdz - Udziela Seweryn, 1892, Żargon złodziejski we Lwowie (rękopis; cyt. za: Rak Maciej, 2016, Kilka uwag o socjolekcie przestępczym polszczyzny przedwojennego Lwowa, w: Socjolingwistyka 30, s. 133-145).

\section{Bibliografia}

Allan Keith / Burridge Kate, 2006, Forbidden Words. Taboo and the Censoring of Language, Cambridge.

AQTAY Gulayhan / JANKowski Henryk, 2011, Słownik kazachsko-polski, Kraków.

BASAJ Mieczysław, SiatKowski Janusz, 1977, Przegląd wyrazów uważanych w literaturze naukowej za bohemizmy (cz. XIV), w: Studia z Filologii Polskiej i Słowiańskiej 16, s. 5-40.

BAudouin De Courtenay Jan Niecisław, 1891, O zadaniach językoznawstwa, w: Prace Filologiczne 3, nr 1, s. 92-115.

Bezlitosne prawa ulicy. Ćmy nocne w poszukiwaniu blasków życia. Wytycha nawala, 1927, w: Ekspress Wieczorny Ilustrowany V, nr 83, s. 4.

Brzezina Maria, 1986, Polszczyzna Żydów, Warszawa/Kraków.

ХоБзей Наталя / Спмович Оксана / ЯстремськА Тетяна / Дидик-Меуш Ганна, 2012, Лексикон львівський. Поважн о і на жарт, Львів. (Hoвzes Natalâ / Simovič Oksana / Âstrems'KA Tetâna / Didik-Meuš Ganna, 2012, Leksikon l'vivs'kij. Považn o i na žart, L'viv).

DĄBRowsKa Anna, 1990, Zniekształcanie obrazu rzeczywistości przez użycie pewnych środków językowych (eufemizm i kakofemizm), w: Bartmiński J. (red.), Językowy obraz świata, Lublin, s. 215-227.

DĄBRowsKa Anna, 1994, Eufemizmy współczesnego języka polskiego, Wrocław.

DĄiRRowska Anna, 1998, Słownik eufemizmów polskich, czyli w rzeczy mocno, w sposobie łagodnie, Warszawa.

DĄBRowska Anna, 2002, Stereotyp polskiego słownictwa erotycznego, w: Skibińska E./Cieński M. (red.), Język - stereotyp - przekład, Wrocław, s. 69-75.

DĄBRowsKa Anna, 2009, Zmiany obszarów podlegających tabu we współczesnej kulturze, w: Dąbrowska A. (red.), Język a Kultura, t. 21. Tabu w języku i kulturze, Wrocław, s. 173-196.

Delesalle Georges, 1896, Dictionnaire argot-Français \& français-argot, Paris.

Dicţionarul limbii române, I - II (A - L), 1913-1940, Bucureşti.

Филин Федот П. (ред.), 1979, Словарь русских народных говоров. Вып. 15, Ленинград. (FILIN Fedot P. (red.), 1979, Slovar' russkih narodnyh govorov. Vyp. 15, Leningrad).

ГорьАч Олекса, 1983, Арѓо в Україні, Львів. (Gorbač Oleksa, 1983, Arŕo v Ukraïni, L’viv).

Grabias Stanisław, 1988, Socjolingwistyczne perspektywy badań nad ekspresywnością języka, Socjolingwistyka 8, s. 35-43. 
ГРАчев Михаил А., 2003, Словарь тысячелетнего русского арго (27000 слов и выражений), Москва. (Gračev Mihail A., 2003, Slovar’ tysâčeletnego russkogo argo (27000 slov i vyraženij), Moskva).

GrochowsKi Maciej, 1995, Słownik polskich przekleństw i wulgaryzmów, Warszawa.

GrzegorczyK Piotr, 1924, Język żydowski (żargon). Samouczek dla Polaków (gramatyka ćwiczenia - słownik), Lwów/Warszawa.

GüNTHER Louis, 1910, Beiträge zur Systematik und Psychologie des Rotwelsch und der ihm verwandten deutschen Geheimsprachen, w: Archiv für Kriminologie (Kriminalanthropologie und Kriminalistik) 38, s. 193-289.

GÜNTHER Louis, 1912, Beiträge zur Systematik und Psychologie des Rotwelsch und der ihm verwandten deutschen Geheimsprachen, w: Archiv für Kriminologie (Kriminalanthropologie und Kriminalistik) 48, s. 331-358.

GüNTHER Louis, 1914, Beiträge zur Systematik und Psychologie des Rotwelsch und der ihm verwandten deutschen Geheimsprachen, w: Archiv für Kriminologie (Kriminalanthropologie und Kriminalistik) 56, s. 41-71.

Habela Jerzy / KuRzowa Zofia, 1989, Lwowskie piosenki uliczne, kabaretowe i okolicznościowe do 1939 roku, Kraków.

HAYARD Napoléon, 1907, Dictionnaire Argot-Français, Paris.

ImieLiŃski Kazimierz, 1980, Seksuologia kulturowa, Warszawa.

Ермакова Ольга П. / ЗЕмская Елена А. / Розина Раиса И., 1999, Слова, с которыми мы все встречались. Толковый словарь общего жаргона, Москва. (ERмAKova Ol'ga P. / ZeмSKAÂ Elena A. / Rozina Raisa I., 1999, Slova, s kotorymi my vse vstrečalis'. Tolkovyj slovar' obŝego žargona, Moskva).

KAMIŃSKi Jan Maurycy, 1875, Prostytucja, Warszawa.

KAMLER Marcin, 1991, Świat przestępczy w Polsce XVI i XVII stulecia, Warszawa.

KAnia Stanisław, 1976, „Kobieta lekkich obyczajów” w języku polskim, w: Studia i Materiały Wyższej Szkoły Pedagogicznej w Zielonej Górze II, s. 53-64.

KARPIŃSKI Marek, 2010, Najstarszy zawód świata. Historia prostytucji, Warszawa.

KLEPSCH Alfred, 2004, Westjiddisches Wörterbuch. Auf der Basis dialektologischer Erhebungen in Mittelfranken, t. 1, Tübingen.

KLUGE Friedrich (red.), 2001, Etymologisches Wörterbuch der deutschen Sprache, Berlin/New York.

Kociemba-Żulicka Justyna, 2011, Mały słownik erotyzmów polskich, Ostrów Wielkopolski.

KRóTKI Zuzanna, 2014, Eufemistyczne nazwy stosunku seksualnego w historii języka polskiego, w: Przyklenk J. (red.), Bogactwo polszczyzny w świetle jej historii, t. 5, Katowice, s. 140-153.

Kurzowa Zofia, 1983, Polszczyzna Lwowa i kresów południowo-wschodnich do 1939 roku, Warszawa/Kraków.

KuŹMA-MarkowsKa Sylwia, 2013, Wiele twarzy „nierządu”. Prostytucja w międzywojennym Wilnie, w: Rodak M. (red.), Margines społeczny Drugiej Rzeczypospolitej, Warszawa, s. 291 309.

КвеСЕЛЕвич Дмитрий И., 2003, Толковый словарь ненормативной лексики русского языка, Москва. (Kveselevič Dmitrij I., 2003, Tolkovyj slovar' nenormativnoj leksikirusskogo âzyka, Moskva).

Lehr-SpŁawiŃski Tadeusz, 1939, Przyczynki etymologiczne. 1. Pol. praca. 2. Pol. szubrawiec, szubrawy, w: Polono-Slavica ofiarowane prof. dr. Henrykowi Ułaszynowi przez Koło Slawistów Studentów Uniwersytetu Poznańskiego im. J. Baudouina de Courtenay, Poznań, s. 26-30.

Lernell Leszek, 1974, Przestępczość seksualna. Zagadnienia prawne i kryminologiczne, w: Imieliński K. (red.), Seksuologia społeczna, Warszawa, s. 486-487.

LEWINSON Jacek, 1999, Słownik seksualizmów polskich, Warszawa. 
MaŁocha Agnieszka, 1994, Żydowskie zapożyczenia leksykalne w socjolekcie przestępczym, w: Anusiewicz J./Siciński B. (red.), Język a kultura, t. 10. Język subkultur, Wrocław, s. 135-170.

MARCINIAK-FiradZa Renata, 2013, Nazwy osobowych wykonawców czynności w gwarach małopolsko-mazowieckiego pogranicza językowego, cz. I. Studium słowotwórczo-leksykalne, Łódź.

Michalewski Kazimierz, 1972, Udział imion własnych we wzbogacaniu apelatywnych zasobów słownikowych, w: Rozprawy Komisji Językowej Łódzkiego Towarzystwa Naukowego 18, s. $101-131$.

MıнĂILĂ Gheorghe, 1960, Împrumuturi vechi sud-slave în limba română, Bucureşti.

Mєотек Mieczysław (oprac.), 1989, Gwara lwowska w pierwszym półwieczu XX wieku, Londyn.

МокиЕнко Валерий М. / НикитинА Татьяна Г., 2000, Большой словарь русского жаргона, Санкт-Петербург. (МокіENko Valerij M. / Nikitina Tat'âna G., 2000, Bol’šoj slovar' russkogo žargona, Sankt-Peterburg).

Mrongowiusz Krzysztof Celestyn, 1823, Dokładny Niemiecko-Polski Słownik/Ausführliches Deutsch-Polnisches Wörterbuch, Königsberg.

Никитина Татьяна Г., 2003, Словарь молодёжного сленга 1980-2000 гг., Санкт-Петербург. (Nikitina Tat'âna G., 2003, Slovar' molodëžnogo slenga 1980-2000 gg., Sankt-Peterburg).

Ожегов Сергей И. / ШвЕдовА Наталия Ю. (ред.), 1993, Толковый словарь русского языка. Москва. (OžEgov Sergej I. / Švedova Nataliâ Û. (red.), 1993, Tolkovyj slovar’ russkogo âzyka, Moskva).

Pacula Jarosław, 2009, O homofobii z perspektywy językowej, w: Świat i Słowo 1(12), s. 241 $-253$.

PaCula Jarosław, 2012, Polskie i rosyjskie egzoetnonimy i przezwiska Żyda w kontekście stereotypu językowego, w: Mitrenga B. (red.), Linguarum Silva 1. Opozycja - przeciwieństwo - kontrast w języku, Katowice, s. 135-148.

Pacula Jarosław, 2017, Prezerwatywa, kondom, gumka - o nazwach pewnego środka antykoncepcyjnego i ochronnego w historii polszczyzny, w: Półrocznik Językoznawczy Tertium 2(2), s. $1-21$.

Peisert Maria, 1994, On i ona we współczesnej polszczyźnie potocznej, w: Anusiewicz J./Handke K. (red.), Język a Kultura 9. Płeć w języku i kulturze, Wrocław, s. 97-119.

PfeIFER Wolfgang (red.), 1989, Etymologisches Wörterbuch des Deutschen, Berlin.

ПриЕмышева Марина, 2009, Тайные и условные языки в России XIX в. Часть I, Санкт-Петербург. (Priemyševa Marina, 2009, Tajnye i uslovnye âzyki v Rossii XIX v. Čast' I, SanktPeterburg).

PrZYbyLSKa Renata, 1987, Współczesne polskie słownictwo erotyczne, w: Preyzner M. (red.), Język - Teoria - Dydaktyka. Materiały VIII Konferencji Młodych Językoznawców-Dydaktyków (Karpacz 3 - 6.03.1983), t. 8, Kielce, s. 97-109.

PuZYNina Jadwiga, 1986, O elementach ocen w strukturze znaczeniowej wyrazów, w: Biuletyn Polskiego Towarzystwa Językoznawczego 40, s. 121-128.

Reczek Stefan, 1968, Podręczny słownik dawnej polszczyzny, cz. 1. Staropolsko-nowopolska; cz. 2. Nowopolsko-staropolska, Wrocław/Warszawa/Kraków.

ReJTER Artur, 2014, „Mój chłopak, facet z plakatu, ciota darkroomówka...”. Wizerunek mężczyzny w gejowskiej literaturze popularnej, w: Rejter A. (red.), Język Artystyczny, t. 15. Język(i) kultury popularnej, Katowice s. 65-87.

ReJTER Artur, 2016, Mężczyzna obnażony? Tytuły aktów męskich w polskiej sztuce współczesnej, w: Mariak L./Rychter J. (red.), Współczesny i dawny obraz mężczyzny w języku, Szczecin, s. $197-209$.

RIEGER Janusz / MASOJĆ Irena / RutKowska Krystyna, 2006, Słownictwo polszczyzny gwarowej na Litwie, Warszawa. 
RoDAK Mateusz, 2007, Prostytucja w Lublinie w dwudziestoleciu międzywojennym, w: Żarnowski

J. (red.), Badania nad dziejami społecznymi XIX i XX wieku, Warszawa, s. 379-390.

RYTTER Grażyna, 1992, Wschodniosłowiańskie zapożyczenia leksykalne w polszczyźnie XVII wieku, Łódź.

Schmidt Joel, 1996, Słownik mitologii greckiej i rzymskiej, tłum. B. Sęk, Katowice.

SiKORSKA-KulESZA Jolanta, 2004, Zło tolerowane. Prostytucja w Królestwie Polskim w XIX wieku, Warszawa.

SKowroneK Bogusław, 2012, Językowe konceptualizacje czynności autoerotycznych. Rekonesans lingwistyczno-kulturowy, w: Studia de Cultura 4, s. 148-157.

СолгАник Григорий Я., 2004, Толковый словарь. Язык газеты, радио, телевидения, Москва. (SolganiK Grigorij Â., 2004, Tolkovyj slovar'. Âzyk gazety, radio, televideniâ, Moskva).

ШАНСКИй Николай М. / ИвАНОв Валерий В. / ШАНСКАЯ Татьяна Б. (ред.), 1971, Краткий этимологический словарь русского языка, Москва. (ŠANSKIJ Nikolaj M. / IvANOv Valerij V. I ŠANSKAÂ Tat'âna B. (red.), 1971, Kratkij ètimologičeskij slovar' russkogo âzyka, Moskva).

ШАТАЛАвА Любоў Ф., 1975, Беларускае дыялектнае слова, Мінск. (ŠATALAVA Lûboy̆ F., 1975, Belaruskae dyâlektnae slova, Minsk).

ШАХматов Алексе́й А. / ЧЕРнышёв Васи́лий И. (ред.), 1956, Словарь современного русского языка в 17 томах. Том 5, Москва/Ленинград. (ŠAhmATOV Alekséj A. / ČERnYŠËV Vasílij I. (red.), 1956, Slovar' sovremennogo russkogo âzyka v 17 tomah. Tom 5, Moskva/Leningrad).

TReimer Karl, 1937, Das tschechische Rotwelsch. Entstehung und Schichten, Heidelberg.

Virmaître Charles, 1894, Dictionnaire d'argot fin-de-siècle, Paris.

ВАхитов Салават В., 2007, Карточная терминология и жаргон XIX века, Москва. (VAнітоV Salavat V., 2007, Kartočnaâ terminologiâ i žargon XIX veka, Moskva).

WeXLER Paul, 1983, „Hebräische und aramäische Elemente in den slavischen Sprachen. Wege, Chronologien und Diffusionsgebiete, w: Zeitschrift für Slavische Philologie 43, nr 2, s. 229-279.

WeXLER Paul, 1987, Explorations in Judeo-Slavic linguistics, Leiden.

WeXLER Paul, 1990, Shțudies in Yidisher Shprakhforshung, Tübingen.

WiDŁAK Stanisław, 1963, Tabu i eufemizm w językach nowożytnych, w: Biuletyn Polskiego Towarzystwa Językoznawczego 22, s. 93-102.

ZAPOLSKa Gabriela, 1911, Śmierć Felicyana Dulskiego, Warszawa.

ZIMNOwODA Joanna, 2005, Wyzwisko - specyficzny rodzaj form adresatywnych (o uniwersalności negatywnych zdarzeń komunikacyjnych), w: Dąbrowska A./Nowakowska A. (red.), Język a Kultura, t. 17. Życzliwość i agresja w języku i kulturze, Wrocław, s. 273-282.

\section{Vocabulary regarding "the oldest profession in the world" in Polish criminal jargon from the 19th and the beginning of the 20th century}

The author presents an erotic lexicon belonging to the category of "prostitution" and appearing in historical criminal jargon. He excerpted lexical material from Polish historical studies from the 19th century and the beginning the 20th century ( 38 words). In the article the author presents the provenance of some expressivisms. He analyses less familiar and forgotten names of brothel, prostitute and pimp: i.e.: bajzel, majdan, binia, nafke, marucha, lupa, chonte, babustyna, szantrapa, rachla, gonia, wytyczka, przydupnik, maciornik, luj, bratpolski, alfons). Most of the studied words constitute neo-semantism, less often - borrowings. The author presents the etymology of this vocabulary, but he 
also hypothesises the origin of several lexemes. He puts the analysed words in the context of linguistic and cultural taboos (he mentions euphemisation and vulgarisation). The text invites discussion; some of the author's observations provoke debate.

Keywords: criminal jargon, erotic lexis, etymology, semantics, diachronic linguistics. 